\title{
Åter i stöpsleven: \\ Personlig assistans mellan marknad och reglering
}

\author{
AGNETA HUGEMARK
}

1994 års assistansreform innebar ett tydligt brott med tidigare etablerade välfärdslösningar. Inte minst innebar den att marknadsbeslut gavs ett betydande utrymme över tjänstens organisering. Dels gavs privata företag, kooperativ och andra producenter rätt att etablera sig på assistansmarknaden. Dels gavs personer med funktionshinder rätt att på egen hand upphandla personlig assistans bland existerande producenter. Idag

syns på nytt tecken på en politisk omorientering i det statliga utredningsväsendet. Tilltron till marknaden förefaller ha minskat och byråkratiska och professionella lösningar efterfrågas åter.

\section{Inledning}

Under senare decennier har en mängd olika så kallade marknadsreformer genomförts på välfärdsområdet. ${ }^{1}$ Därmed har en strävan efter enhetlighet och likabehandling i hög grad ersatts av en strävan efter varia-

Agneta Hugemark är fil. dr. i sociologi, sociologiska institutionen, Uppsala universitet tion, valfrihet och flexibilitet. Det sagda innebär dock inte att statlig kontroll och reglering har mist betydelse i sammanhanget. Hur mycket utrymme som lämnats

1 Denna artikel är skriven inom det FAS-finansierade projektet "Kampen om alternativen. Om heterogeniserande och homogeniserande krafter på en marknadsreformerad välfärdssektor» (nr. 2001-2494). 
till marknaden att bestämma varierar, men staten har inte på något område abdikerat fullständigt. Även om viss detaljreglering har avvecklats så kvarstår alltså den statliga styrningen i någon form och omfattning. Till detta kommer att, sedan marknadsreformernas sjösättning, också kan iakttas nya former av statlig styrning, såsom utvärdering och olika typer av standards (jfr. Brunsson \& Jacobsson 1998a). Genom förändringar i styrningens form och innehåll, kan staten därför efterhand till och med komma att återta delar av det handlingsutrymme som tidigare överlämnats till marknaden (jfr. Brunsson \& Jacobsson 1998b, Lindqvist \& Borell 1998, Blomqvist 2005). Denna artikel handlar om hur en sådan »återreglering" idag ter sig aktuell på ett speciellt välfärdsområde, närmare bestämt när det gäller marknaden för personlig assistans för personer med funktionshinder. Mitt syfte är att visa hur dagens diskussion på den statliga politiska nivån skiljer sig på betydande vis från den politiska viljeyttring som för drygt tio år sedan kom till uttryck i den så kallade assistansreformen. Medan den senare var tydligt påverkad av marknadsekonomiska ideal, har den statliga politiska diskussionen sedan dess istället allt mer kommit att problematisera viktiga byggstenar i reformen. Mitt syfte är närmare bestämt att visa att de idéer och förslag som idag förs fram från statliga aktörer inom politik och förvaltning, uttrycker ett tydligt skifte i synen på marknadens möjligheter att åstadkomma en önskvärd situation på assistansområdet.

I det följande tecknar jag först en bakgrund till marknadsreformernas inträde på välfärdsområdet i allmänhet och på handi- kappområdet i synnerhet. Med detta visar jag hur assistansreformens utformning liksom dess konkreta effekter kan anses vara den marknadslösning som mer än andra uppfyller de marknadsekonomiska idealen. På inget annat område har närmare bestämt konsumenter och producenter erhållit så stort formellt utrymme att utan statlig inblandning påverka tjänsternas karaktär. Därefter visar jag hur statliga aktörer sedan reformens ikraftträdande har problematiserat vissa av reformens reella utfall samt hur de efterhand också tagit initiativ till ökad kontroll och styrning av assistansmarknaden. I den avslutande delen sammanfattar jag dagsläget i den statligt förda diskussionen. Trots att en mängd problematiseringar och regleringsförslag under åren har formulerats, har i dagsläget förslagen inte genomförts i praktiken. En tolkning av detta är att marknadsmodellen fortfarande har ett betydande inflytande men att den är föremål för allt starkare ifrågasättanden. ${ }^{2}$

\section{Marknad och välfärdsstat}

En mängd olika reformer har under de senaste decennierna genomförts i syfte att öka marknadsinslagen i den offentliga sek-

2 Det empiriska material som har använts är skriftligt offentligt material från följande aktörer under tiden 1995 och framåt: Statlig beslutande nivå: Riksdag och Socialutskott. Statlig verkställande niva: Regering och Socialdepartement. Statlig förvaltande nivå: Socialstyrelsen, Arbetsmiljöverket (tidigare Arbetarskyddsstyrelsen), Riksförsäkringsverket, Riksrevisionen (tidigare Riksrevisionsverket), Arbetsmiljöinspektionen (tidigare Yrkesispektionen). 
torn. ${ }^{3}$ Den typ av reform som kommer närmast den marknadsteoretiska förebilden är reformer av så kallad kundvalskaraktär. Med detta avser jag reformer som, för det första, syftar till att åstadkomma en verksamhet styrd av medborgarnas individuella val, för det andra ger det individuella valet direkt betydelse för hur ekonomiska resurser fördelas mellan olika tjänsteproducenter, för det tredje skapar utrymme för producenter med olika ägarformer, organisation och affärsidé att konkurrera med varandra om medborgarnas ekonomiska resurser.

Denna typ av reformer har under den senaste tjugoårsperioden genomförts på en mängd olika områden. Så har vi som svenska medborgare erhållit en betydligt större formell möjlighet att själva välja vilken tandläkare vi vill gå till, var våra barn ska gå på dagis eller i skola, liksom vilken vårdcentral eller vilken hemtjänstenhet vi vill vända oss till. Förändringar av detta slag kan betraktas som ett resultat av ett ifrågasättande av hela den välfärdsmodell som byggdes upp i Sverige under tiden efter andra världskriget och fram till 1970-talet. En viktig del av kritiken utgick från ifrågasättande av välfärdsstatens byråkratiska karaktär. Tidigare hade rättssäkerhet, likabehandling och effektivitet varit viktiga politiska motiv för byråkratiska beslutsvägar och förvaltningsformer. Under 1970-talet förändrades den politiska debatten och andra effekter av byråkratiseringen lyftes fram. Byråkratin började istället beskrivas som ett hot mot medborgarnas möjlighet till inflytande, insyn och integri-

3 Förslagen syftar i varierande omfattning på förändringar i reglering, finansiering och/eller produktion. tet. Byråkratin sades ha lett till en välfärdsstat som av medborgarna upplevdes som rigid och "stelbent" (se t.ex. Ahrne 1985). Invävd i byråkratikritiken fanns dessutom ofta en kritik mot professionella gruppers relativt starka ställning. Vad som då lyftes fram var närmare bestämt den professionella, vetenskapligt grundade, kunskapens roll i välfärdsstaten. I Sverige har, i kanske högre grad än de flesta andra länder, professionella grupper haft en mycket framträdande roll i välfärdsstatens organisationer. Denna roll har motiverats och legitimerats med att socialpolitiska beslut och insatser genom detta har grundats på relevant sakkunskap och professionella hänsyn och därmed kunnat utformas till trygghet och omsorg för berörda medborgare. Vad professionskritiken istället tog fasta på var att professionell kunskap också är en källa till makt för dess utövare och att välfärdsstatens klienter, som en konsekvens av detta, erfor maktlöshet i mötet med läkare, psykologer och andra experter. ${ }^{4}$

I denna historiska situation började alltså marknadslösningar - och då speciellt så kallade kundvalsmodeller - att föras fram som alternativ för välfärdsstatens organisering. Bilden av marknaden som en väg till valfrihet och mångfald ställdes med detta mot bilden av byråkratin som en väg till likriktning, tvång och stelbenthet. ${ }^{5}$ Assistansområdet blev det område på

4 För en mer utförlig diskussion om kritiken mot "den traditionella svenska välfärdsmodellen", se Hugemark \& Wahlström (2002 s. 18-24).

5 Om hur byråkratins respektive marknadens positiva respektive negativa sidor kan ligga till grund för samhällsdialog, se Ahrne (1995). 
vilket frågan om vad som ska produceras och vem som ska konsumera vad, i högre grad än på andra områden har lämnats över till marknaden - konsumenter och producenter - att avgöra. I jämförelse med förberedandet av andra kundvalsreformer förefaller den partipolitiska enigheten om assistansreformens form och innehåll dessutom ha varit påfallande. ${ }^{6}$ De inledande stegen till assistansreformen togs under 1980-talet då den socialdemokratiske vice socialministern tillsatte en arbetsgrupp för utredning av handikappområdet. 1989 tillsattes en statlig handikapputredning. Då den följande handikappolitiska propositionen presenterades 1993 hade ett maktskifte skett i den svenska riksdagen och socialministerposten innehades av folkpartiet. Enligt Barbro Lewin togs riksdagsbeslut i frågan i stort sett i enlighet med den föregående utredningens förslag (Lewin 1998). Åtminstone när det gäller personlig assistans, var utredningens förslag i väsentliga avseenden också ett resultat av, och i samstämmighet med, relativt starka krav från organisationer som artikulerade intressen från funktionshindrade själva. En aktör som var speciellt drivande i frågan var den så kallade Independent Living-rörelsen (se t.ex. Larsson \& Larsson 2004 samt Hugemark \& Wahlström 2002). Grundläggande i rörelsens ideologi är ett starkt hävdande av funktionshindrades rätt att själva bestämma över sin situation, inte minst i fråga om behov av privat och intim karaktär. Redan under 1980-talet bildade Independent Living-rörelsen brukarkoope-

6 För partipolitiska strider om den s.k. skolpengen, se Mannerfelt (2005). rativ med personlig assistans. Med reformens ikraftträdande blev denna möjlighet således mer generell.

\section{Marknad och personlig assistans}

1994 sjösattes alltså en reform - här benämnd assistansreformen - vilken i hög grad kan ses som ett uttryck för en strävan att öka marknadens betydelse på bekostnad av centrala statliga regler och direktiv. I korthet innebar reformen att vissa personer med funktionshinder fick möjlighet till stöd och hjälp i vardagen genom så kallad personlig assistans. Typexempel på uppgifter som assistansen ska gälla är hjälp med påoch avklädning, personlig hygien och kommunikation. I reformens "kärndokument", Lag (1993:387) om stöd och service till vissa funktionshindrade (LSS) lyfts begreppen integritet, självbestämmande och autonomi fram på ett sätt som tydligt visar de politiska ambitionerna. Förutsättningarna att nå dessa mål framstår i sin tur som $\mathrm{i}$ hög grad avhängiga möjligheterna att låta individens egna erfarenheter, kunskaper och val avgöra hur hjälpinsatserna ska utformas (se t.ex. SOU 1992:52 s. 478). Med reformen skapades formella möjligheter till inflytande i två steg. Dels gavs assistansmottagaren rätt att själv bestämma vilken producent som ska tillhandahålla tjänsten samt rätten att byta assistentproducent $i$ den händelse hon blev missnöjd med hjälpen. Dels gavs hon rätt till ett långtgående inflytande över assistansens konkreta uppläggning och utförande, inklusive anställning av personliga assistenter. Inflytande av det 
senare slaget förutsätts gälla oavsett vilken assistansproducent hon väljer att anlita. ${ }^{7}$

Som assistanskonsument är man alltså formellt helt fri att välja vilken producent man vill av dem som finns på marknaden. Som assistansproducent har man en, relativt sett, mycket stor frihet att etablera sig på marknaden i den form och med den typ av utbud man själv föredrar. Assistansanordnare behöver inte få sin verksamhet godkänd av stat eller kommun för att få starta sin verksamhet. ${ }^{8}$ Konkret har reformen inneburit att personer som blir beviljade personlig assistans erhåller ekonomiska resurser från kommunen (upp till 20 timmar/vecka) och försäkringskassan (överstigande 20 timmar/vecka). För dessa medel kan hon eller han välja att upphandla sin assistans hos kommunen eller någon icke kommunal assistansproducent. Den organisation som väljs blir då assistenternas arbetsgivare. Medborgaren ifråga kan också välja att på egen hand organisera sin assistans, inklusive att själv vara arbetsgivare.

Vilka aktörer finner vi då på den reellt existerande assistansmarknaden i Sverige? Om vi börjar med konsumentsidan, så ger en studie på området vid handen att cirka 14000 svenska medborgare uppbär ekono-

7 För en problematisering av förhållandet mellan dessa två typer av inflytande, se Hugemark (2004).

8 Visserligen måste de, liksom organisationer i allmänhet, följa vissa regler för att få verka som till exempel aktiebolag eller ekonomiska föreningar. Dessa föreskrifter inbegriper emellertid inte regler som på något sätt styr själva verksamhetsinnehållet, utan blott organisationernas kapitalhantering, beslutsformer och dylikt (se t.ex. Hemström 2002). miska medel för personlig assistans. Denna grupp varierar dock stort inbördes ifråga om hur mycket assistanstid de bedömts ha rätt till. Variationen sträcker sig från personer som bedömts ha behov av blott ett fåtal timmar assistans per vecka, till personer som bedömts ha behov av personlig assistans dygnet runt (Larsson 2004). Detta betyder i sin tur att antalet personliga assistenter anställda per assistansmottagare varierar stort. Medan vissa endast har en eller ett par assistenter anställda, har andra ett betydande antal assistenter i sin assistentgrupp. Antalet personer som under ett år är anställda som personliga assistenter beräknas till mellan 40000 och 50000 (Larsson 2004 samt SOU 2005:100). Dessa skiljer sig inbördes åt i en mängd avseenden. Så finner vi här personer som arbetar som assistenter ett fåtal timmar per vecka, liksom de som arbetar heltid. Vidare finns de som är tillsvidareanställda, liksom de som är timanställda.

Också ifråga om producenter verksamma på assistansmarknaden existerar en påfallande heterogenitet. En relativt aktuell statlig utredning beräknar antalet icke kommunala assistansorganisationer till cirka 330 stycken verksamma i Sverige (SOU 2005:100s. 82). Mellan dessa organisationer finns stora skillnader. Dels finner vi betydande variation avseende företagsformer och företagsstorlek. Dels finner vi påtagliga skillnader mellan de assistanstjänster som bjuds ut på marknaden. De senare skillnaderna avser bland annat vilka komponenter utöver personlig assistans (såsom stöd och handledning, stöd i rättsprocesser och vid myndighetskontakter, information om rättigheter och förändringar i lagstiftning) 
som ingår i "tjänstepaketet", såväl som variationer i själva assistansens mål och former. ${ }^{9}$ Till utbudet från dessa assistansorganisationer ska läggas den personliga assistans som varje kommun är skyldig att tillhandahålla sina invånare. Enligt en aktuell beräkning av assistansmottagares fördelning mellan olika producentalternativ anlitar cirka 62 procent kommunen, cirka 23 procent anlitar privata företag och cirka tolv procent anlitar kooperativ. Cirka fyra procent av assistansmottagarna är själva arbetsgivare och några - under en procent - anlitar fler än en assistansanordare, det vill säga har olika arbetsgivare till olika assistenter (SOU 2005:100 s. 80). ${ }^{10}$

\section{Statliga bekymmer}

Som visats är funktionshindrades möjligheter till valfrihet och självbestämmande själva kärnan i assistansreformens intentioner och mål. Med tiden har emellertid flera aspekter och förhållanden gällande detta blivit föremål för statliga frågor och diskussion. En aspekt av förändringarna kan

9 För en mer detaljerad bild av heterogeniteten i företagsform, storlek och tjänsteutbud på assistansmarknaden, se Hugemark \& Mannerfelt 2003 samt Hugemark 2004.

10 Då det idag inte finns någon helt tillförlitlig registrering av icke kommunala assistansanordnare ska dock noteras att dessa siffror är behäftade med osäkerhet. Relativt säkert verkar emellertid vara att andelen assistansmottagare som väljer privata assistansorganisationer kontinuerligt har ökat sedan reformens ikraftträdande samt att de lokala variationerna i fördelning är stora (SOU 2005: 100 s 80-81). uttryckas som att sociala relationer mellan olika aktörer har förts in i diskussionen. Från en situation där assistansmottagaren så gott som helt själv befann sig i fokus för intresset, har med tiden i allt högre grad också personliga assistenter och assistansorganisationer börjat diskuteras och deras relationer till assistansmottagare börjat problematiseras. Med detta har också aktualiserats ett antal generella statliga regelverk gällande ansvar, anställningsvillkor och trygghet, vilka under assistansreformens förberedande och sjösättning i relativt liten utsträckning förefaller ha diskuterats.

Fortsättningsvis visar jag hur helt centrala delar i assistansreformen kommit att problematiseras, hur problembeskrivningarna har underbyggts samt hur lösningar på problemen ifråga har formulerats. Jag inleder varje tema med att visa hur det kommer till uttryck i regeringens direktiv till den nu arbetande statliga "Assistanskommittén". Kommittén tillsattes 2004 för att genomföra en översyn av personlig assistans och i regeringsdirektiven framgår vilka områden man vill ha belysta. Dels efterfrågas en översyn av kostnadsutvecklingens orsaker och om rutiner och riktlinjer för biståndsbedömningen. Dels efterfrågas en översyn om hur personlig assistans organiseras och om assistansutbudets kvalitet (Socialdepartementet 2004a). ${ }^{11}$ Denna artikel handlar om frågor av det senare slaget. Det är i intresset för organisation och kvalitet som

11 Enligt ursprungsdirektiven skulle ett slutbetänkande presenteras senast den 31/12 2006. I ett tilläggsdirektiv (Socialdepartementet 2005) sköts tidpunkten för slutbetänkande upp till den 31/32007. 
jag menar att vi finner tecken på att de tydligt marknadsinfluerade utgångspunkterna i assistansreformen idag är föremål för omprövning. Med utgångspunkt i nämnda direktiv går jag därför tillbaka i tiden och visar hur dessa teman har behandlats i tidigare statliga dokument. ${ }^{12}$

\section{Lämpliga arbetsförhållanden?}

En grundläggande del i assistansreformen var som jag tidigare påtalat, assistansmottagares inflytande över assistansens uppläggning, liksom över vilken kompetens och utbildning assistenten behöver. En annan sida av detta är personliga assistenters arbetsvillkor, vilket är något som efterhand aktualiserats på statlig nivå. En uppgift som regeringen givit den nu sittande assistanskommittén, är att ngenomföra en studie av yrket som personlig assistent och belysa de personliga assistenternas arbetsvillkor, arbetsmiljö och anställningsformer» (Socialdepartementet 2004a s. 13). Detta statliga intresse är dock på intet sätt nytt, utan har kommit till uttryck i flera sammanhang tidigare. Ett tillfälle var vid en sammankomst hos Socialutskottet 1997. En av de

12 I denna artikel avgränsar jag mig till en analys av hur, sedan assistansreformens införande, statliga bekymmer har förts fram gällande utbud och organisation av personlig assistans. I ett annat sammanhang (Hugemark 2006) visar jag hur, utöver detta, också andra effekter av reformen har blivit problematiserade, nämligen assistansreformens kostnader samt, inte minst, huruvida existerande regler och riktlinjer för biståndsbedömning förmår skilja ut de medborgare som reformen »egentligen« var tänkt för. utifrån inbjudna talarna var en direktör från Socialstyrelsen som i sitt anförande uttryckte bekymmer över assistenternas arbetsförhållanden. "Vi har gjort en uppföljning som visar att det inom denna yrkesgrupp har varit en mycket stor rörlighet. Gruppen deltidsanställda är mycket stor, och det råder för många en osäkerhet om arbetsvillkoren" (Socialutskottet 1997/98 s. 25). Här finns således en tidig indikation på att något ifråga om personliga assistenters situation uppfattas som problematiskt.

Fyra år senare tillsatte regeringen en arbetsgrupp med uppgift att manalysera förutsättningarna för att underlätta rekryteringen av personliga assistenter". En omständighet som redan i uppdraget förutsattes vara viktig, var just assistenternas arbetsförhållanden. Arbetsgruppen hävdar i sin rapport att det finns många brister $i$ assistenters arbetsmiljö. Man hänvisar här speciellt till en undersökning från 1999 gjord av Yrkesinspektionen (nuvarande Arbetsmiljöinspektionen). Också här förefaller intresset ha vidgats gentemot det resonemang som låg till grund för assistansreformens tillkomst. När arbetsgruppen till exempel talar om bristande introduktion i arbetet och personliga assistenters bristande kunskaper om förhållningssätt, är det $i$ allt väsentligt assistenters - inte assistansmottagares - beskrivningar av situationen som åsyftas. Och när arbetsgruppen talar om arbetsledares alltför höga arbetsbelastning, så är det inte personer med funktionshinder som åsyftas utan personal som är anställd $i$ assistansorganisationerna.

Också frågan om assistenters utbildning uppmärksammas av regeringens arbetsgrupp. Man framhåller att det inte finns 
något formellt utbildningskrav för att få arbeta som personlig assistent och redogör för variationer i rutiner för utbildning och handledning bland assistansorganisationer. Också på denna punkt förefaller det klart att utgångspunkterna skiljer sig från dem som låg till grund för assistansreformen. Enligt de senare var frånvaron av generella, formella utbildningskrav för assistenter snarare en poäng än ett problem, närmare bestämt som en grund för funktionshindrades möjligheter till inflytande över hjälpen.

En ytterligare punkt på vilken arbetsgruppens rapport är intressant, är att den knyter samman personliga assistenters intressen med assistansmottagarnas. En god utformning av arbetsmiljön, skriver man, wär viktig för att assistenterna ska kunna känna sig trygga och säkra i sitt arbete. Samtidigt är den också viktig för brukaren i den meningen att en god arbetsmiljö bidrar till att denna får tillgång till en bra och säker assistans" (Socialdepartementet 2001 s. 47).

En annan statlig aktör som deltagit i diskussionen om assistentersarbetsförhållanden är Arbetsmiljöverket. ${ }^{13}$ Denna myndighet har relativt tydligt artikulerat vissa problem gällande mötet mellan assistansreformen och andra regelverk. I en rapport från 2001 skriver verket att de lagar som reglerar assistansverksamheten $\mathrm{i}$ vissa delar är motstridiga och att det finns en gråzon där det råder oklarheter om var gränserna går mellan LSS och arbetsmiljölagstiftningen. Man börjar med

13 Ett ytterligare sammanhang i vilket assistenters arbetsförhållanden, närmare bestämt deras anställningsförhållanden, kommenterats i myndighetssammanhang, är av Riksförsäkringsverket $\mathrm{i}$ en översyn av assistansersättningen (RFV 1999:1). att slå fast att LSS är en rättighetslag som "ger den funktionshindrade självbestämmande, bland annat över vilka assistenter denna vill anställa och över innehållet i assistansen« (Arbetsmiljöverket 2001). Denna lag, skriver verket, kan emellertid komma i konflikt med andra mål och andra regelverk. I illustrerande syfte nämner man problem som kan uppstå då assistansmottagaren röker. „Det är självklart att man får röka i sitt hem, men det är knappast förenligt med en god arbetsmiljö att personal utsätts för passiv rökning"(Arbetsmiljöverket 2001).

Något år senare återkommer Arbetsmiljöverket med en rapport som helt ägnas personliga assistenters arbetsmiljö hos kommunala såväl som hos övriga typer av arbetsgivare. ${ }^{14}$ I den står att läsa att man ofta får frågor om relationen mellan LSS och arbetsmiljölagstiftningen, och om LSS "står över" arbetsmiljölagen eller tvärtom (Arbetsmiljöverket 2002). Det förefaller som om verket i dessa fall brukar bli frågeställaren ett tydligt svar skyldig. "Svaret på denna fråga är att det ingenstans finns uttryckt att den ena lagen skulle stå över den andra. Arbetsmiljöverket vill därför ... poängtera att båda lagarna ska följas». Ansvaret för hur detta ska göras för man tillbaka till lokala aktörer, nämligen till kommunala och andra assistansanordnare: "Som arbetsgivare måste man hela tiden söka lösningar som inte strider mot någon av lagarna» (Arbetsmiljöverket 2002). Med detta kan konstateras att assistansmottagares rätt att på egen hand avgöra assistansens form och innehåll, under åren har kommit

14 Assistenter med assistansmottagaren själv som arbetsgivare, dock undantagna. 
att problematiseras från flera olika perspektiv. Som vi ska se har också andra av reformens grundbultar blivit diskuterade.

\section{Lämpliga assistenter?}

Också funktionshindrades rätt att avgöra vem som ska anställas som personlig assistent var som jag framhållit ett nyckelinslag i reformen. Även i denna fråga kan vi märka förskjutningar i den statligt förda diskussionen. Ett ytterligare tema när personlig assistans idag diskuteras är nämligen att vissa av de personer som anställs inte passar, inte är lämpliga som assistenter. I förut nämnda regeringsdirektiv uppmärksammas speciellt de assistenter som har en nära släktrelation till assistansmottagaren. Regeringen skriver att kommittén ska analysera på vilket sätt "den enskildes möjligheter till självständighet och oberoende påverkas av att denne har stöd av personliga assistenter. En aspekt som kommittén skall belysa i det här sammanhanget är fördelar och nackdelar med att ha anhöriga som assistenter" (Socialdepartementet 2004a s. 11).

I övriga dokument som jag har granskat är det dock i första hand nackdelar som diskuterats. Ett indikerat problem har att göra med assistansens omfattning $i$ tid räknat. Riksrevisionsverket (numera Riksrevisionen) är en myndighet som har intresserat sig för denna fråga. I en rapport som utkom relativt snart efter assistansreformens ikraftträdande, skriver man att wantalet ersättningstimmar/tenderar/ att bli högt då anhöriga är anställda som personliga assistenter" (RRV 1995 s. 83). Min tolkning av detta är att Riksrevisionsverket antar att anhöriga är aktiva och framgångsrika i den process då assistansbehovet bedöms av offentliga myndigheter. Detta implicerar i sin tur att funktionshindrade med anhöriga vid sin sida kan lyckas få en mer omfattande personlig assistans än de annars skulle ha fått. Det vill säga att assistansen därmed kommer att kosta staten mer än den annars skulle ha gjort.

Ett ytterligare problem med anhöriga assistenter som Riksrevisionsverket formulerar är att en sådan lösning, »kan komma att motverka reformens syfte att underlätta för den funktionshindrade att komma ut $\mathrm{i}$ daglig verksamhet, få eget boende etcu (RRV 1995 s. 83). Medan det förra problemet förefaller formulerat med utgångspunkt $\mathrm{i}$ en oro för assistansreformens kostnader, förefaller detta problem snarare formulerat med utgångspunkt i hänsyn till funktionshindrades livssituation. Här ger verket även ett konkret exempel på vad man menar. Man hänvisar till ett fall där en vuxen man har flyttat hem från en gruppbostad. »Hans föräldrar och syskon anställs som personliga assistenter. Han slutar på dagcenterverksamheten och andra aktiviteter som var kopplade till gruppboendet. Både kommunen och försäkringskassan anser att han fått det sämre» (RRV $1995 \mathrm{s.}$ 83).

Med den sista anmärkningen framgår det att Riksrevisionsverket utgår från andra hänsynstaganden än de som fördes fram då assistansreformen sjösattes. Liksom då man tidigare diskuterade personliga assistenters arbetsförhållanden är det inte otvetydigt assistansmottagarens erfarenheter och önskemål som ligger till grund för problemformuleringen. När verket uttalar sig om funktionshindrade personers möjligheter till en god livssituation utgår man istället från 
synpunkter inhämtade från företrädare för kommunal och statlig byråkrati.

Några år senare uttalar sig också Riksförsäkringsverket i frågan om lämpliga och olämpliga assistenter och stödjer härvid uppfattningen att anhöriga kan utgöra ett problem. Liksom tidigare Riksrevisionsverket framhåller man att anhöriga assistenter kan hindra funktionshindrade personers möjligheter till frigörelse från familjen. "Det finns en risk för att den handikappolitiska målsättningen att möjliggöra frigörelse från familjen inte kan uppfyllas. Beroendeförhållanden inom familjen kan istället knytas hårdare» (RFV 1999 s. 35).

I en rapport från Riksrevisionen fem år senare aktualiseras åter frågan om anhöriga. Med hänvisning bland annat till ovan anförda studier formuleras ett antal risker med att anhöriga är anställda som assistenter. Problemen gäller att föräldrar kan bli beroende av sitt barns assistansersättning för sin försörjning och att det nekonomiska beroendet kan skapa incitament att maximera antalet timmar med assistansersättning", att familjen blir mindre benägen att låta den funktionshindrade familjemedlemmen flytta till eget boende, samt att anhöriga kombinerar sitt arbete som personlig assistent med ett heltidsarbete utanför hushållet. ${ }^{15}$ I denna rapport formuleras dock även möjliga fördelar med att anhöriga arbetar som personliga assistenter. För det första menar Riksrevisionen att det kan innebära en högre grad av kontinuitet $\mathrm{i}$ assistansen, "som annars ofta präglas av stor personalomsättning". För det andra säger man att det kan "vara värdefullt för den enskilde att hjälpen ges av någon man känner och har förtroende för». För det tredje framhålls att arbetet som personlig assistans för många anhöriga har winneburit att man nu får ersättning för arbete som tidigare varit oavlönat" (Riksrevisionen 2004 s. 49).

Som jag tidigare framhöll framstår dock, i statliga dokument, anhöriga som assistenter generellt sett utgöra ett problem snarare än en tillgång. Att frågan om lämpliga och olämpliga assistenter överhuvudtaget aktualiseras är, menar jag, i sin tur ytterligare ett tecken på att dagens diskussion om personlig assistans har förändrats gentemot tidigare. Från att det förut var en grundläggande poäng och något som togs för givet, att personer med funktionshinder själva bäst vet och kan finna en person som passar som assistent, till en problematisering av just detta. Denna problematisering tycks baserad på antagandet att assistansmottagaren inte alltid vet bäst och inte alltid väljer optimalt, samt att andra än hon själv
15 Redan 1995 problematiserade RRV förhållandet att anhöriga kombinerar assistanssysslan med ett annat, ordinarie, arbete. "Föräldrar kan t.ex. arbeta utanför hemmet och ändå vara anställda som personliga assistenter till sina barn på heltid». Arbetsveckorna för anställda anhöriga, hävdar man, överstiger ofta 40 timmar. 1999 kommer åter anhörigas arbetstid upp till diskussion, nu av RFV (1999 s. 35). Fallstudier har, anför man, visat att vissa anhöriga som arbetar som assistenter har arbetsveckor på upp till 95 timmar, om man lägger samman deras assistentjobb med deras ordinarie arbete. Till detta kommer att verket, åter med hänvisning till Riksrevisionsverket, som ett problem lyfter fram förhållandet att i "flera familjer /hela försörjningen består/ av assistansersättningen". RRV anför att rimligheten i ersättningens omfattning i dessa fall kan ifrågasättas. 
kan ha inflytande över valet, det vill säga att hon befinner sig i en situation där hon kan ha mer eller mindre inflytande och makt.

\section{Lämpliga assistansanordnare?}

Vi har ovan sett hur statliga dokument, sedan reformens genomförande har kommit att rymma problematiseringar av assistansmottagarens mandat att på egen hand bestämma när och hur assistansen ska utformas, liksom av hennes mandat, alternativt hennes förmåga, att själv välja vem som ska ge assistansen. Problematiseringarna riktar dock in sig på något olika förhållanden. I det första fallet gäller saken att assistansmottagarens sätt att leva och leda arbetet kan bli till nackdel för den person som arbetar som assistent. I det andra fallet är det problem som formuleras snarare att assistansmottagaren inte har förmåga eller möjlighet att välja den assistent som hon "egentligen" har behov av. Andra än hon själv, närmare bestämt anhöriga, antas också kunna ha inflytande över att anställningen påbörjas och/eller upprätthålls. I båda fallen är det ett sätt att resonera som - såvitt jag kunnat finna - inte står att finna i den statligt förda diskussionen under assistansreformens förberedande.

I detta avsnitt ska vi betrakta hur också en tredje grundbult i assistansreformen med tiden har kommit att problematiseras. Det gäller närmare bestämt antagandet om att valfrihet och kvalitet främjas genom marknadsrelationer och att därför assistansproducenter bör lämnas relativt fria att själva utforma sin verksamhet. De som gör det på ett undermåligt sätt kommer, enligt samma antagande, att ratas av assistanskonsumenterna. Även detta har som sagt problematiserats. Därmed har också antagandet om funktionshindrade personers rätt att fritt välja assistansanordnare blivit mindre självklart. Vad som börjat formuleras är nämligen farhågor för, eller rent av påståenden om, att alla assistansanordnare inte är av det slag att man kan vara säker på att de tillhandahåller en tjänst av god kvalité. Enligt tidigare anförda regeringsdirektiv ska assistanskommittén kartlägga och analysera icke kommunala verksamheter "samt överväga och föreslå hur lämpliga former av tillsyn av enskilda verksamheter med personlig assistans skall utformas" (Socialdepartementet 2004a). Redan för ett antal år sedan fick dock Socialstyrelsen regeringens uppdrag att speciellt behandla privata assistansanordnares kvalitet. Myndigheten "uppfattade uppdraget så att det gällde risken för sämre kvalitet på assistans utförd av privata anordnare beroende på bristande tillsyn" (Socialstyrelsen 2000 s .1). Vad fann man då?

Med utgångspunkt i data insamlad från en mängd olika aktörer involverade i frågan sökte Socialstyrelsen svar på frågor om kvalitet, kvalitetskriterier och kvalitetsproblem i privat anordnad assistans. ${ }^{16}$ Den grundläggande frågan om huruvida det existerar kvalitetsbrister hos privata assistansanordnare gavs dock inget tydligt svar. Att det är viktigt med kvalitet och kvalitetsutvecklig förutsätts. Vad kvalitet är, definieras emellertid inte konsekvent. Så antas t.ex. förekomst av utbildning, introduktion och handledning för personliga assistenter, liksom förekomst

16 Länsstyrelser, brukare, handikapporganisationer, kommuner samt privata anordnare. 
av verksamhetsuppföljning, vara uttryck för god kvalitet. Vilken typ av utbildning eller vad introduktionen, handledningen och verksamhetsuppföljningen ska innehålla, diskuteras inte närmare. Sammanfattningsvis utmynnar Socialstyrelsens kvalitetsundersökning i ett långt ifrån entydigt svar.

I en tidigare nämnd rapport formulerar Riksrevisionen några år senare tydligare än Socialstyrelsen de risker man ser med privata assistansordnare. Man konstaterade att privata företag anordnade assistans åt 20 procent av brukarna 2002, men att deras andel av marknaden ökar. Ökningen kan, säger man vidare, «i viss mån bero på en aktiv marknadsföringu. En viss skepsis uttrycks gentemot vissa av de argument som står att finna i marknadsföringen: "Vissa företag lockar med löften om att brukaren ska få pengar över till annat än assistans, att antalet timmar ska maximeras (genom att företagen hjälper till vid överklaganden i domstol/ar), osv." (Riksrevisionen 2004 s. 46). Vi såg tidigare hur anhöriga antogs kunna driva upp kostnaderna för personlig assistans. Här är det istället assistansanordnande organisation som antas kunna göra detta. ${ }^{17}$

17 Det är emellertid betydligt fler risker än så med de privata assistansföretagen som formuleras i denna skrift. En risk som formuleras är att privata företag strävar efter att hålla nere kostnader och maximera vinster. »Företaget ... har möjlighet att hålla nere kostnaderna för löner, ob-tillägg, utbildning, handledning och andra omkostnader. För privata anordnare innebär lägre kostnader en högre vinst. Företagens vinstmarginaler kan bli stora eller mycket stora. Detta har framhållits av flera av dem som intervjuats i granskningen, speciellt företrädare för kommunerna" (Riksrevisionen 2004 s. 57).
En ytterligare omständighet som av Riksrevisionen hävdas existera är att "privata anordnare väljer lätta fallı (Riksrevisionen 2004 s. 58). I detta sammanhang dyker åter funktionshindrades anhöriga upp i problemdiskussionen, men nu på ett annat sätt än tidigare. $\mathrm{Nu}$ förutsätts de bidra till att privata assistansanordnare kan få förmånliga(re) ekonomiska villkor för sin verksamhet. Riksrevisionen hävdar nämligen att personer som har anhöriga som assistenter inte sällan har privata företag som assistansanordnare. "Anhöriga assistenter ställer ofta låga krav på utbildning och handledning och de anmäler sig sällan sjuka. För anordnaren innebär det även lägre administrativa kostnader för t.ex. rekrytering" (Riksrevisionen 2004 s. 58). Här, till skillnad från i diskussionen om lämpliga och olämpliga assistenter, är det inte de anhöriga i sig som beskrivs som problem, utan vissa assistansordnare som antas välja vissa assistansmottagare och assistenter framför andra.

"Det är bara de privata företagen som har möjlighet att välja brukare. Det förekommer också att privata assistansanordnare drar sig undan en viss brukare för att denna anses vara för dyr. Detta är ett naturligt sätt för vinstdrivande företag att agera och inte fel i lagens mening. Det kan dock upplevas kränkande för den berörda brukaren" (Riksrevisionen 2004 s. 58).

I aktuella diskussioner på statlig nivå är det, till skillnad från tidigare, således inte bara personer med funktionshinder som antas välja det för henne eller honom mest fördelaktiga alternativet. Också vissa produ- 
center antas ha stort inflytande över vilka kontrakt som ingås och - i förlängningen vilka funktionshindrade som har möjlighet att välja vad på assistansmarknaden.

\section{Statliga regleringsförslag}

Hittills har jag sökt renodla problembeskrivningar i de dokument jag studerat. I realiteten förekommer dock ofta beskrivningen av ett visst problem mer eller mindre sammanvävt med förslag till lösning av detsamma. Redan vid ett tidigare nämnt möte hos Socialutskottet 1997, fördes fram förslag till ökad styrning av assistansområdet. För att garantera att insatserna blir av god kvalitet, sa en av talarna, skulle Socialstyrelsen gärna se watt de personliga assistenternas yrkesstatus och deras möjligheter till utbildning, handledning och stöd uppmärksammades mer, också i förhållande till kraven på en verkligt god insats från dem som utnyttjar assistans" (Socialutskottet 1997/98 s. 25). Dessa förslag ligger väl i linje med dem som fördes fram av Arbetsmiljöverket fem år senare. I en av mig tidigare anförd rapport finns relativt omfattande förslag till statlig styrning. Verkets förslag kan sammanfattas i två linjer: för det första tydligare arbetsledning och stöd från assistansanordnarens sida, för det andra formellare utbildningskrav och fastare anställningsvillkor för personliga assistenter (Arbetsmiljöverket 2002). Dessa förändringar antas skapa en bättre arbetsmiljö för personliga assistenter och dessutom öka förutsättningarna att kunna fylla framtidens personalbehov. Arbetsmiljöverket hänvisar i detta sammanhang också till Socialdepartementets utredning "Rekrytering av personliga assistenter" (Socialdepartementet 2001). Man stöder de relativt omfattande förslag som departementet där för fram, närmare bestämt bättre lönevillkor, förstärkt kompetensutveckling och forskning, informationssatsning om assistansyrket, vägledning och kunskapsunderlag till arbetsgivare, uppföljning och utvärdering med fokus på rekrytering, tillsyn inom arbetsmiljöområdet samt vissa hjälpmedel i samband med personlig assistans (Arbetsmiljöverket 2002).

Om förslagen ovan syftar till att komma tillrätta med problem gällande assistenters arbetsvillkor, har jag ifråga om de problem som utryckts med anhöriga som assistenter inte funnit några explicita förslag på reglering och styrning. Möjligen kan en del av problemen antas lösas genom just redovisade förslag. Om, till exempel, ökade utbildningskrav och mer reglerade arbetstider formaliseras på assistansområdet, kan måhända intresset från anhörigas sida antas bli lägre. Som vi ska se nedan finns också beröringspunkter mellan diskussioner om olämpliga assistenter och lösningar av problem med olämpliga assistansanordnare.

Närmare bestämt har under åren förts fram förslag på såväl tillsyn och reglering av icke kommunala assistansanordnare, som förslag på någon typ av tillstånd för att få etablera sig på marknaden. Ett sätt att se på dessa förslag är att betrakta dem som en ytterligare väg för staten att styra över assistenters utbildning och arbetsförhållanden samt över vem som ska anställas, nämligen genom att kontrollera att assistansorganisationer verkligen följer de mer eller mindre tydligt uttalade statliga rekommendatio- 
nerna i dessa frågor. När regeringsdirektiven efterfrågar förslag på »hur lämpliga former av tillsyn ska utformas", är det alltså långt ifrån första gången som den frågan är på tapeten. Redan år 2000 intresserade sig Socialstyrelsen (i enlighet med regeringens regleringsbrev) för frågan om tillsyn av privata assistansanordnare. Orsaken till uppdraget, såsom det tolkades av Socialstyrelsen, var "risken för sämre kvalitet på assistans utförd av privata anordnare beroende på bristande tillsyn" (Socialstyrelsen 2000 s. 2, kursiv borttagen). Att Socialstyrelsen, som jag tidigare nämnde, vid detta tillfälle inte lyckades precisera några kvalitetskriterier, än mindre bedöma privata assistansorganisationers kvalitet, hindrade inte att man tog sig an uppgiften att utreda förutsättningarna för att bedriva tillsyn.

De synpunkter och intressen som kommer till uttryck i nämnda skrift är dock många och inbördes motstridiga. A ena sidan framförs spörsmål om verksamheternas kvalitet. $\AA$ andra sidan framförs, med utgångspunkt i marknadsargument, synpunkter om att statlig tillsyn är överflödig. "Kunden avgör själv vem han/hon vill vara kund hos. Därmed sker en tillsyn på bästa sätt, dvs. av kunden «. ${ }^{18}$ Rapporten som helhet utmynnar inte heller i något tydligt ställningstagande i frågan, snarare anas tveksamhet då man skriver att man inte för närvarande finner någon direkt anledning att utvidga länsstyrelsernas tillsynsansvar. Här blir Socialstyrelsen - liksom tidigare Arbetsmiljöverket - explicit ifråga om konflikten mellan assistansreformens

18 En av de tillfrågade länsstyrelserna citerad i Socialstyrelsen (2000 s. 22). utgångspunkter och statlig reglering. Det finns, skriver man, risk för att utökad tillsyn »skulle komma i konflikt med LSS:s intentioner om inflytande och självbestämmande för den enskilda brukaren. Principen om tilltron till den enskildes förmåga att själv bäst kunna utforma sin assistans är en vägledande princip för hela reformen« (Socialstyrelsen 2000 s. 8).

Också Riksförsäkringsverket har formulerat förslag till lösningar på problem med assistansanordnares organisation. Då beskrivs frågorna emellertid i hög grad som arbetsmiljöfrågor snarare än som kvalitetsfrågor. Man understryker att en viktig aspekt vid rekrytering av assistenter är att arbetsgivarens organisation fungerar på ett tillfredsställande sätt. Verket understryker härvid att man tidigare föreslagit "att Socialstyrelsen ska ha ett övergripande tillsynsansvar för all verksamhet i form av anordnande av personlig assistans och att länsstyrelsen ska ha den direkta tillsynen över anordnarna» (RFV 2002-05-06, Dnr 01739/2002).

I slutet av 2004 tar så regeringen ett ytterligare steg ifråga om styrning av assistansmarknaden. I ett tilläggsdirektiv tillför man den sittande assistanskommittén en uppgift. Utöver att belysa »ämpliga former av tillsyn av enskilda verksamheter med personlig assistans", formuleras ett ytterligare uppdrag:

Regeringen ger kommittén $i$ uppdrag att även analysera förutsättningarna för att införa krav på tillstånd för verksamheter med personlig assistans. I den mån kommittén finner att förutsättningar finns för att införa krav på tillstånd skall kommit- 
tén lämna förslag till de författningsförändringar och andra åtgärder som uppdraget kan ge anledning till (Socialdepartementet 2004b).

Med detta ser vi att förslagen till statlig styrning av assistansmarknaden har stärkts ytterligare. Vad som ovan aktualiseras är inte endast styrning »i efterhand» av redan existerande verksamhet. Här talas också om möjligheterna att införa statliga etableringskrav, det vill säga att på statlig nivå fastställa vilka kriterier som privata assistansproducenter ska uppfylla för att överhuvudtaget få komma in på marknaden och erbjuda sina tjänster till personer som har beviljats personlig assistans.

\section{Mellan marknad och politik}

Ovan har jag sökt tydliggöra hur den statliga diskussion som idag förs i väsentliga avseenden skiljer sig från den klart marknadsinspirerade diskussion som låg till grund för och satte sin prägel på assistansreformen. Dagens diskussion har beskrivits med utgångspunkt i tre olika problemkomplex: personliga assistenters arbetsförhållanden, personliga assistenters lämplighet, respektive assistansanordnares lämplighet. Samtliga dessa problemområden berör i sin tur några helt grundläggande byggstenar i assistansreformen: funktionshindrade personers möjligheter att påverka assistansens utförande, deras val av personliga assistenter samt deras val av assistansanordnare.

Utvecklingen kan därmed ses som en kamp om vad som även fortsatt ska lämnas till marknaden - konsumenter och produ- center - att bestämma, och vad som ska återtas av staten att reglera och kontrollera. Den utveckling som härvid har visats kan beskrivas som en förskjutning från en statlig marknadsdiskurs till en statlig regleringsdiskurs, det vill säga en diskurs av betydligt mer marknadsskeptiskt slag. Medan den förra kännetecknades av en hög grad av tilltro till marknadens förmåga att åstadkomma en effektiv verksamhet av god kvalitet, uttrycker den senare på avgörande punkter tvivel angående detta. Med en renodling av de bärande punkterna i respektive diskurs kan skillnaderna uttryckas på följande sätt: I marknadsdiskursen definierades byråkratiska och professionellt styrda verksamheter som något som skapade problem för berörda medborgare. Privata producenter, konkurrens och konsumentval blev de lösningar som fördes fram som alternativ och som sedan blev grundläggande inslag i 1994 års assistansreform. I regleringsdiskursen, däremot, har en förändring skett. $\mathrm{Nu}$ är det istället privata producenter, konkurrens och konsumentval som problematiseras. Ett ökat inslag av byråkratisk styrning och professionell kompetens hos personliga assistenter framstår i detta perspektiv som lösningar.

Utvecklingen (illustrerad i tablån på nästa sida) kan också ses som ett resultat av att andra grupper har börjat lyckas etablera som hegemoniska sina tolkningar av vad som är legitima sociala behov och hur de ska tillgodoses (jfr. Fraser 2003). Till skillnad mot för 15 år sedan framförs idag argument formulerade av grupper i välfärdsstatens byråkratier, snarare än argument från organisationer som företräder personer med funktionshinder. Ett led i denna förändring

Agneta Hugemark: Åter i stöpsleven. Personlig assistans mellan... 


\section{Marknadsdiskurs}

Byråkratisering

Professionalisering

Privata producenter

Konsumentval problem

problem

lösning lösning
Regleringsdiskurs

lösning

lösning

problem

problem är att också andra än funktionshindrades behov har förts in i diskussionen, närmare bestämt de personliga assistenternas. Av detta skäl kan sägas att förändringen i den statligt förda diskussionen inte bara har inneburit en rörelse bort från en marknadsdiskurs mot en mer regleringsvänlig dito. Den inbegriper också ett relativt tydligt handikappolitiskt skifte i synen på funktionshindrades kompetens och möjligheter. Idag framförs som vi såg åter argument och förslag som uttrycker tilltro till såväl byråkratisk som professionell kompetens.

När den nu arbetande assistanskommittén i ett delbetänkande presenterar förslag på statlig tillsyn såväl som på införande av statliga tillstånd för privata assistansproducenter, är emellertid den definitiva färdriktningen långt ifrån klar (SOU 2005:100).
Många diskussioner torde återstå. Såsom inte minst visat sig i den politiska debatten om kundval på skolmarknaden, kan frågan om hur krav som dessa mer precis ska utformas bli lång och intensiv (Mannerfelt 2005). Om förslagen på ökad statlig styrning accepteras politiskt blir rimligen nästa steg att avgöra vad tillsynen ska ta fasta på och vad tillstånden ska postulera. Oavsett hur detta i sina detaljer kommer att utformas förefaller vi i dagsläget dock åter kunna se en utveckling mot ökad enhetlighet och statligt överinseende när det gäller organisering av hjälp till personer med funktionshinder. Detta kan i sin tur beskrivas som ett tydligt steg närmare den "traditionella svenska modell« vars grundbultar marknadsförespråkare för cirka 25 år sedan började utmana.

\section{Referenser}

Ahrne, Göran (1985) Den irriterade medborgaren.

Stockholm: Stockholms universitet, Sociologiska institutionen.

Ahrne, Göran (1995) „Medborgaren vid det demokratiska gränssnittet«. I Kenneth Abrahamsson \& Ulla Björklund (red.) Den lilla samhällsdialogen. Forskning om medborgarkontakter, yrkeskompetens och kunskapsstöd i en decentraliserad förvaltning. Civildepartementet, Ds. 1995:39.

Arbetsmiljöverket (2001) Personlig assistans - ett arbetsfält med brukare, ansvar och variation, Rapport 2001:15.

Arbetsmiljöverket (2002) Personliga assistenters arbetsmiljö. Ett riksövergripande projekt, Rapport 2002:5.

Blomqvist, Paula (2005) "Privatisering av sjukvård: politisk lösning eller komplikation?" Socialvetenskaplig tidskrift, vol. 12 nr. 2-3, s. 169-189.

Brunsson, Nils \& Jacobsson, Bengt (red.) (1998a) 
Standardisering. Stockholm: Nerenius \& Santérus.

Brunsson, Nils \& Jacobsson, Bengt (1998b) „Den viktiga standardiseringen." I Nils Brunsson \& Bengt Jacobsson (red.) Standardisering. Stockholm: Nerenius \& Santérus.

Fraser, Nancy (2003) „Kampen om behoven: Utkast till en kritisk teori om den senkapitalistiska politiska kulturen." I Nancy Fraser Den radikala fantasin. Mellan omfördelning och erkännande. Stockholm: Daidalos.

Hemström, Carl (2002) Bolag - Föreningar - Stiftelser. En introduktion. Stockholm: Norstedts Juridik AB

Hugemark, Agneta \& Wahlström, Karin (2002) Personlig assistans i olika former. Mål, resurser och organisatoriska gränser. FoU-rapport 2002:4, FoU-enheten, Socialtjänstförvaltningen, Stockholms stad.

Hugemark, Agneta (2004) »Med rätt att bestämma själv? 'Exit', 'voice' och personlig assistans.» I Kerstin Gynnerstedt (red.) Medborgarskap och personlig assistans. Lund: Studentlitteratur.

Hugemark, Agneta \& Mannerfelt, Charlotte (2003) Vad är till salu? - om utbud på marknader för grundskola och personlig assistans. FoU-rapport 2003:9, FoU-enheten, Socialtjänstförvaltningen, Stockholms stad.

Hugemark, Agneta (2006) Mellan marknad och politik. Om statlig styrning av marknaden för personlig assistans. FoU-rapport 2006:5, FoUenheten, Stadsledningskontoret, Stockholms stad.

Lag (1993:387) om stöd och service till vissa funktionshindrade.

Larsson, Monica (2004) "Personlig assistent - kompis, startmotor eller någons armar och ben?" I Kerstin Gynnerstedt (red.) Medborgarskap och personlig assistans. Lund: Studentlitteratur.

Larsson, Monica \& Larsson, Stig (2004) Att vara ett mänskligt hjälpmedel. En studie om att arbeta som personlig assistent. Centrum för handikapp- och rehabiliteringsforskning. Lund: Harec press.

Lewin, Barbro (1998) Funktionshinder och med- borgarskap. Tillkomst och innebörd av de två rättighetslagarna omsorgslagen och LSS som komplement till socialtjänstlagen och hälso- och sjukvårdslagen. Socialmedicinsk tidskrifts skriftserie nr 55, Uppsala.

Lindqvist, Rafael \& Borell, Klas (1998) "Inledning: Organisation och välfärdspolitik.» I Rafael Lindqvist (red.), Organisation och välfärdsstat. Lund: Studentlitteratur.

Mannerfelt, Charlotte (2005) Villkorad frihet - om reglering av fristående grundskolor. FoU-rapport 2005:4, FoU-enheten, Socialtjänstförvaltningen, Stockholms stad.

Riksförsäkringsverket (1999) Assistansersättning - översyn av ersättningen för personlig assistans, RFV Anser 1999:1.

Riksförsäkringsverket (2002) Remissvar på Ds 2001:72, Rekrytering av personliga assistenter, Dnr. 01739/2002.

Riksrevisionsverket (1995) Assistansreformen - en granskning av den statliga assistansersättningen till funktionshindrade, RRV 1995:57.

Riksrevisionen (2004) Personlig assistans till funktionshindrade, RIR 2004:7, Stockholm.

Socialdepartementet (2001) Rekrytering av personliga assistenter. Rapport från arbetsgruppen för att underlätta rekryteringen av personliga assistenter, Ds 2001:72.

Socialdepartementet (2004a) Kommittédirektiv. Översyn av personlig assistans för vissa personer med funktionshinder, dir. 2004:107.

Socialdepartementet (2004b) Regeringens tilläggsdirektiv, dir. 2004:179.

Socialdepartementet (2005) Regeringens tilläggsdirektiv, dir. 2005:66.

Socialstyrelsen (2000) Stöd till brukare vid privat anordnadpersonligassistans. Regeringsuppdrag att utreda tillsynsansvaret för privat anordnad Personlig assistans enligt LSS (RuPa).

Socialutskottet (1997/98) Assistansersättningen. Hur fungerar assistansersättningen för personer med stora funktionshinder? Utredningar från Riksdagen, 1997/98:URDI.

SOU 1992:52, 1989 års Handikapputredning, Ett samhälle för alla, Handikapputredningens slutbetänkande. 
SOU 2005:100, På den assistansberättigades uppdrag. God kvalitet i personlig assistans - ändamålsenlig användning av assistansersättning, Delbetänkande av Assistanskommittén.
Sveriges Riksdag, Snabbprotokoll 2002/03:109, Riksdagsdebatt med anledning av Socialutskottets betänkande om översyn.

\section{Summary}

\section{Back in the melting-pot Personal assistance between market and regulation}

During the last few decades, a number of so-called market reforms have been implemented in the Swedish welfare state. As a result, the political ambitions for homogeneity and equal treatment have been replaced to a high degree by the explicit ambition to increase the opportunities for variation, flexibility and individual choice. This, however, does not mean that the central state - parliament, government and national bureaucracy - has given up its influence on what welfare services should be produced and for whom. But the role of politics has changed and new forms for state steering and control have developed. This article deals with the way in which questions of increased state control today are brought to the fore in the political dis- course in one specific area, i.e. regarding personal assistance for individuals with disabilities. The aim is to show how the present discussion on personal assistance differs in important ways from the political manifestation of the will expressed in the assistance reform just over a decade ago. The latter was clearly influenced by economic market ideals, while the political discussion of today to a high degree problematizes important building blocks in the reform. More concretely the aim is to show how the ideas and suggestions that are delivered today by actors in politics and public administration express an evident shift in the confidence in the market as a way to achieve an acceptable situation in the field of personal assistance. 